\title{
In vitro antitumor effects of two novel oligostilbenes, cis- and trans-suffruticosol D, isolated from Paeonia suffruticosa seeds
}

\author{
NADIN MARWAN ALMOSNID ${ }^{1}$, YING GAO ${ }^{1}$, CHUNNIAN HE $^{2}$, HYO SIM PARK $^{1}$ and ELLIOT ALTMAN ${ }^{1}$ \\ ${ }^{1}$ Tennessee Center for Botanical Medicine Research and The Department of Biology, \\ Middle Tennessee State University, Murfreesboro, TN 37132, USA; ${ }^{2}$ Institute of Medicinal Plant Development, \\ Chinese Academy of Medical Sciences, Haidian, Beijing 100193, P.R. China
}

Received July 30, 2015; Accepted November 2, 2015

DOI: $10.3892 /$ ijo.2015.3269

\begin{abstract}
Naturally derived stilbenes have been shown to elicit cytotoxic, anti-steroidal, anti-mutagenic, anti-oxidative, anti-inflammatory, and antitumor bioactivities. Previous phytochemical studies revealed that the seeds of Paeonia suffruticosa are rich in natural stilbenes. In this study the antitumor effects and mechanism of action of the oligostilbene isomers, cis- and trans-suffruticosol D, isolated from the seeds of P. suffruticosa were examined. cis- and transsuffruticosol D exhibited remarkable cytotoxicity against the human cancer cell lines A549 (lung), BT20 (breast), MCF-7 (breast), and U2OS (osteosarcoma), but showed significantly less toxicity to the normal human cell lines HMEC (breast) and HPL1A (lung). We also demonstrated that cis- and transsuffruticosol D exerted their antitumor effects by provoking oxidative stress, stimulating apoptosis, decreasing the mitochondrial membrane potential, inhibiting cell motility, and blocking the NF- $\kappa \mathrm{B}$ pathway in human lung cancer cells. In addition, we evaluated their respective bioefficacy and found that trans-suffruticosol D is more potent than cissuffruticosol D. Collectively, our results suggest that cis- and trans-suffruticosol D could be promising chemotherapeutic agents against cancer.
\end{abstract}

\section{Introduction}

Current cancer medications are costly and often cause serious side effects. The US National Cancer Institute began investigating antitumor plant extracts in the 1960s, and the premise that natural compounds obtained from therapeutic plants could produce anticancer medications has henceforth been of great

Correspondence to: Dr Ying Gao, Tennessee Center for Botanical Medicine Research and The Department of Biology, Middle Tennessee State University, 1301 E Main St, P.O. Box 60, Murfreesboro, TN 37132, USA

E-mail: ying.gao@mtsu.edu

Key words: Paeonia suffruticosa, cis- and trans-suffruticosol D, cytotoxicity, apoptosis, oxidative stress, cell motility research interest. Traditional Chinese medicines (TCMs) using dried plants or plant extracts have provided low cost diet and pharmaceutical therapies for thousands of years and experimental and clinical studies have proven that $>400$ plant species used in TCMs as anticancer herbal medications are significantly effective in the prevention or treatment of various cancers (1-4). However, much work remains to be done to determine the effectiveness of the individual compounds present in the TCMs.

Paeonia suffruticosa, or Paeoniaceae, is a widely utilized Chinese medicinal plant within the Paeonia genus. This genus comprises $\sim 35$ species that are classified into three groups: Oneapia, Paeonia, and Moutan (5). The Cortex Moutan (root cortex) of Paeonia has been recorded by China's Pharmacopoeia as a significant source of herbal medicine (6). Extracts of Paeonia have been shown to possess cytotoxic, antitumor, anti-inflammatory and anti-oxidative activities (5). Previous photochemical research on Paeonia identified $>260$ bioactive compounds, including phenols, monoterpenoidglucosides, paeonols, flavonoids, tannins, steroids, triterpenoids and stilbenes (7). A more recent study showed that the seeds of Paeonia contain considerable quantities of stilbenes compared to the other compounds $(7,8)$.

Stilbenes are a class of polyphenols widely found in plants that contain a 1.2-diphenylethylene nucleus in their structure (9). Stilbenes have aroused great interest due to their antitumor, anti-steroidal, anti-mutagenic, anti-oxidative, anti-malarial, and anti-inflammatory bioactivities (10-16). One well-known example of the stilbenes is resveratrol, and its antitumor activity has been intensively studied. Several in vivo and in vitro studies have shown that resveratrol inhibits the growth of cancer cells and effects various molecular targets associated with cancer progression such as the Wnt signaling pathway, nuclear factor-kappa $\mathrm{B}(\mathrm{NF}-\kappa \mathrm{B})$, and the MAPK/ERK pathway in different types of cancer $(17,18)$.

Previously, two novel stilbenes, cis- and trans-suffruticosol D, were extracted from the seeds of Paeonia (5). The two chemicals have similar structures as the mass fragmentation pattern of trans-suffruticosol D was very similar to cis-suffruticosol D, with cis-suffruticosol D varying only from trans-suffruticosol D in its olefinic hydrogen signal (Fig. 1). In this study, we investigated the antitumor activities of cis-and trans-suffruticosol D and examined how these two chemicals act against cancer cells in vitro. 


\section{Materials and methods}

Plant material and compound isolation. The seeds of P. suffruticosa were collected in Tongling, Anhui, China, and identified in September 2012. A voucher specimen (2012001) has been deposited in the Seed Resource Bank at the Institute of Medicinal Plant Development, Chinese Academy of Medical Sciences and Peking Union Medical College. cis- and trans-suffruticosol D were extracted and isolated from the dried seeds of $P$. suffruticosa as described previously (5). Compounds were re-suspended in dimethyl sulfoxide (DMSO) (Sigma-Aldrich, St. Louis, MO, USA) at a concentration of $10 \mathrm{mM}$ and stored at $4^{\circ} \mathrm{C}$.

Cell culture. Four human cancer cell lines including A549 (lung carcinoma), BT20 (estrogen receptor-negative human breast adenocarcinoma), MCF-7 (estrogen receptor-positive human breast adenocarcinoma) and U2OS (human osteosarcoma) were purchased from American Type Culture Collection (ATCC, Manassas, VA, USA). An A549 cell line that stably expresses green fluorescent protein (GFP) was purchased from Cell BioLabs Inc. (San Diego, CA, USA). A549, A549-GFP and BT20 cells were cultured in RPMI1640 media (Sigma-Aldrich), MCF-7 cells were cultured in DMEM medium (ATCC), and U20S cells were cultured in McCoy's 5A medium (ATCC). As a control, HPL1A cells (human peripheral lung epithelial cells) were obtained from Nagoya University and cultured in DMEM/F12 medium (Sigma-Aldrich); HMEC cells (primary human mammary breast epithelial cells) were purchased from ATCC and cultured in McCoy's 5A medium. HPL1A cells (primary human peripheral lung epithelial cells) were obtained from Nagoya University, Japan, and cultured in DMEM/F-12K medium (Sigma-Aldrich). All medium contained 10\% FBS (Sigma-Aldrich) and 1\% streptomycin and penicillin (SigmaAldrich). These cells were incubated in a humid environment with $5 \% \mathrm{CO}_{2}$ at $37^{\circ} \mathrm{C}$.

Cell proliferation assay. The resazurin reduction reagent AlamarBlue (Invitrogen, Frederick, MD, USA) was used to evaluate the cytotoxicity of the compounds. Cells were plated at a density of $5 \times 10^{3}$ cells per well in 96-well microplates with $100 \mu \mathrm{l}$ culture medium, and were allowed to attach for $16 \mathrm{~h}$ prior to treatment. Next, all the medium was replaced with medium containing the cis- or trans-suffruticosol D compounds at seven different concentrations: $320,100,32,10$, $3.2,1.0$ and $0.32 \mu \mathrm{M}$. $1 \%$ DMSO was used as vehicle control. The cells were placed in an incubator for $48 \mathrm{~h}$ at $37^{\circ} \mathrm{C}$. Cells that were treated with medium containing vehicle only serve as negative control. Subsequently, AlamarBlue solution was added to the medium and the cells were incubated in the $\mathrm{CO}_{2}$ incubator for $1 \mathrm{~h}$. The fluorescent intensity change of the dye was measured at Ex $555 \mathrm{~nm}$ and Em $590 \mathrm{~nm}$ using a plate reader (Molecular Devices, Sunnyvale, CA, USA). The cytotoxicity was examined by determining by $\mathrm{IC}_{50}$, the dose that inhibited 50\% of cell growth, using GraphPad Prism software (GraphPad Software, La Jolla, CA, USA). For the N-acetylL-cysteine (NAC) attenuation assay, the cells were treated with different concentrations of cis- or trans-suffruticosol D followed by incubation with or without $10 \mathrm{mM}$ NAC (Sigma-
Aldrich) for $48 \mathrm{~h}$, and then cell viability was assessed using the AlamarBlue assay.

Apoptosis assay. The FlowCellect Annexin Red kit (EMD Millipore, Billerica, MA, USA) was used to determine the apoptosis rate in A549 cells according to the manufacturer's instructions. Briefly, A549 cells were plated in 96-well plates. After a 24-h treatment with cis- or trans-suffruticosol D at concentrations of 100,32 and $10 \mu \mathrm{M}$, the floating and attached cells were collected for analysis. The cells were centrifuged at $700 \mathrm{x} \mathrm{g}$ for $7 \mathrm{~min}$ and were resuspended in $100 \mu \mathrm{l}$ assay buffer (EMD Millipore). Afterwards, the cells were stained with Annexin V for $15 \mathrm{~min}$ and 7-amino-actinomycin D (7-AAD) for $5 \mathrm{~min}$, and examined with a Guava EasyCyte Flow Cytometer (EMD Millipore). Data were analyzed using Guava InCyte software.

Apoptosis antibody array. The Human Apoptosis Antibody Array kit (RayBiotech, Inc., Norcross, GA, USA) was used to evaluate apoptotic protein expression according to the manufacturer's instructions. A549 cells were plated at 8,000 cells/well intensity in a 96-well plate and then treated with cis- or trans-suffruticosol D at a concentration of $50 \mu \mathrm{M}$ for $6 \mathrm{~h}$. The cells were lysed in lysis buffer with protease inhibitors. The cell lysates were concentrated using a protein concentration column (EMD Millipore) to a total protein concentration of $2 \mathrm{mg} / \mathrm{ml}$. The samples were then diluted 10 -fold with assay buffer and incubated with an array membrane for $2 \mathrm{~h}$ at room temperature, and washed with washing buffer for five times. Subsequently, the cocktail of biotin-conjugated antibody mix was added to the membrane and incubated overnight at $4^{\circ} \mathrm{C}$. The samples were then incubated with HRP-conjugated streptavidin for $2 \mathrm{~h}$ at room temperature and chemiluminescence substrate was used to detect the signal. Image Studio software (LI-COR Biotechnology, Lincoln, NE, USA) was used to quantify the intensity of each array dot and then normalized to the internal control.

Oxidative stress assay. The Hitkit oxidative stress kit (Thermo Scientific, Waltham, MA, USA) was used to determine the generation of reactive oxygen species (ROS) according to the manufacturer's instructions. Briefly, A549 cells were treated with cis- or trans-suffruticosol D for $24 \mathrm{~h}$, fixed with warm $37 \%$ formaldehyde and stained with Hoechst and dihydroethidium (DHE) dye for $30 \mathrm{~min}$ at $37^{\circ} \mathrm{C}$ with $5 \% \mathrm{CO}_{2}$. Doxorubicin (DOX) at $1 \mu \mathrm{M}$ concentration was used as a positive control and cells treated with vehicle only were used as negative control. ROS generation in the nuclei was indicated by the production of the fluorescent ethidium, and assessed by measuring the nuclear fluorescent intensity using an ArrayScan VTI Highcontent screening (HCS) reader (Thermo Scientific). Images were acquired and data was analyzed by vHCS Scan software.

Cell motility assay. A 96-well collagen plate (Corning, Corning, NY, USA) was coated with blue fluorescent beads (Life Technologies, Eugene, OR, USA) as follows. The beads were centrifuged for $1 \mathrm{~min}$ at $14,000 \mathrm{~g}$ and washed twice with PBS, then $75 \mu 1$ beads were added to each well of the 96-well collagen plate and incubated for $1 \mathrm{~h}$ at $37^{\circ} \mathrm{C}$. The cells were seeded on the lawn of fluorescent beads and the sizes of the 


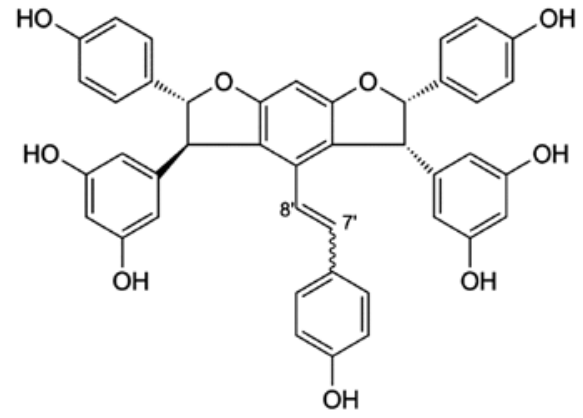

trans-suffruticosol D: 7', 8' = trans cis-suffruticosol D: 7', 8' = cis

Figure 1. Chemical structures of cis- and trans-suffruticosol D.

tracks generated by migrating cells were measured. After the plate was washed 5 times with PBS, A549-GFP cells were seeded at 500 cells/well in the coated plate and incubated for $1 \mathrm{~h}$ at $37^{\circ} \mathrm{C}$. Subsequently the cells were treated with different concentrations of cis- or trans-suffruticosol D in medium containing $10 \%$ FBS for $18 \mathrm{~h}$. Cells treated with serum-free medium serve as the negative control and cells treated with medium containing 10\% FBS serve as the positive control. Cell tracks were imaged using an Arrayscan VTI HCS reader (Thermo Scientific) and the data were analyzed by vHCS Scan software. The mean of the full track area per cell for the test compound and the controls was calculated.

Multi-parameter cytotoxicity assay. HCS analysis was used to measure nuclear morphology, cell membrane permeability, and mitochondrial membrane potential changes, the three parameters associated with cytotoxicity. A549 cells were treated with different concentrations of cis- or trans-suffruticosol D for $24 \mathrm{~h}$. The cells were then fixed and stained with a warm solution containing Hoechst dye, membrane permeability dye, and mitochondrial membrane potential dye (Thermo Scientific). Cells were imaged using an Arrayscan VTI HCS reader (Thermo Scientific). Data on nuclear size, cell permeability, and mitochondria membrane potential were collected and analyzed using vHCS Scan software.

Western blot analysis. A549 cells were treated with $50 \mu \mathrm{M}$ of cis-or trans-suffruticosol D for $3 \mathrm{~h}$ then incubated with $10 \mathrm{ng} / \mathrm{ml}$ of TNF- $\alpha$ for $30 \mathrm{~min}$. Cells treated with the NF- $\mathrm{BB}$ inhibitor Bay11-7082 (10 $\mu \mathrm{M})$ (Sigma-Aldrich) were used as a positive control, and cells treated with vehicle only were used as a negative control. After treatment, the cells were lysed using M-PER mammalian protein extraction reagent (Thermo Scientific) containing proteinase and phosphatase inhibitors (Sigma-Aldrich) and centrifuged at 13,000 rpm for $5 \mathrm{~min}$ at $4^{\circ} \mathrm{C}$. A Pierce BCA protein assay kit (Thermo Scientific) was used to determined protein concentrations. Proteins were separated on a 4-20\% Tris-glycine gel (Thermo Scientific), and electrophoretically transferred to a PVDF membrane. The following primary antibodies were used: phosphorylated-

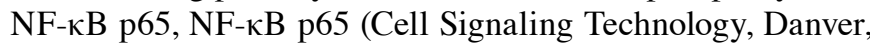
MA, USA) and actin (Santa Cruz Biotechnology, Dallas, TX, USA). The membrane was incubated with the primary antibodies at a 1:1,000 concentration at $4^{\circ} \mathrm{C}$ overnight. After
Table I. $\mathrm{IC}_{50}$ values of cis- and trans-suffruticosol D in selected cancer and normal cell lines.

\begin{tabular}{lrr}
\hline $\mathrm{IC}_{50}(\mu \mathrm{M})$ & trans-SD & \multicolumn{1}{c}{ cis-SD } \\
\hline A549 & $11.9 \pm 1.2$ & $17.1 \pm 1.0$ \\
BT20 & $9.9 \pm 3.8$ & $13.4 \pm 2.5$ \\
MCF-7 & $15.8 \pm 1.6$ & $46.8 \pm 3.3$ \\
U2OS & $11.3 \pm 2.3$ & $24.6 \pm 4.4$ \\
HPL1A & $78.3 \pm 6.1$ & $177.5 \pm 9.3$ \\
HMEC & $146.3 \pm 2.7$ & $269.5 \pm 2.2$
\end{tabular}

Cells were treated with various concentrations of cis- or trans-suffruticosol D for $48 \mathrm{~h}$, and the viability of cells was evaluated with the AlamarBlue dye. Data are expressed as mean \pm SD, and experiments were performed in triplicates.

washing with $1 \mathrm{X}$ PBS 5 times, the membrane was incubated for $2 \mathrm{~h}$ at room temperature with HRP linked anti-rabbit IgG secondary antibodies. Membranes were developed with chemiluminescent substrates (Thermo Scientific) and scanned with a chemiDoc MP imaging system (Bio-Rad, Hercules, CA, USA).

$N F-\kappa B$ nuclear translocation assay. The Multiplexed NF- $\kappa \mathrm{B}$ activation HCS kit (Thermo Scientific) was used to assess $\mathrm{NF}-\kappa \mathrm{B}$ nuclear translocation. A549 cells were pre-treated with different concentrations of cis- or trans-suffruticosol D for $4 \mathrm{~h}$, then $10 \mathrm{ng} / \mathrm{ml}$ of TNF- $\alpha$ (Sigma-Aldrich) was added to the cells for an additional $30 \mathrm{~min}$. After treatment, cells were fixed and permeabilized prior to detection. NF- $\kappa \mathrm{B}$ distribution was detected by adding NF- $\kappa \mathrm{B}$ p65 primary antibodies and then staining with a secondary antibody conjugated with DyLight 549 and Hoechst dye (Thermo Scientific). Cells treated with medium containing only the vehicle were used as negative control, and cells treated with $25 \mathrm{ng} / \mathrm{ml} \mathrm{TNF-} \alpha$ were used as a positive control. Cells were imaged using an Arrayscan VTI $\mathrm{HCS}$ reader. Data on the mean difference of NF- $\kappa \mathrm{B}$ fluorescent intensity between the nuclear and cytoplasmic areas were collected and analyzed by vHCS Scan software.

\section{Results}

Cytotoxicity of cis- and trans-suffruticosol D in lung, breast, and bone cancer cells. After 48-h treatment, both cis- and trans-suffruticosol D showed significant cytotoxic effects against A549 (lung), BT20 (breast), MCF-7 (breast) and U2OS (osteosarcoma) cancer cell lines. $\mathrm{IC}_{50}$ values for cis- and transsuffruticosol D against these cancer cells ranged from 9.93 to $46.79 \mu \mathrm{M}$ as shown in Table I. Interestingly, we observed that trans-suffruticosol D had lower $\mathrm{IC}_{50}$ values $(9.93-15.84 \mu \mathrm{M})$ than cis-suffruticosol D (13.42-46.79 $\mu \mathrm{M})$ in all four cancer cell lines. In addition, both cis- and trans-suffruticosol D showed notably weaker cytotoxicity against normal breast epithelial cells HMEC ( $\mathrm{IC}_{50}$ values of 146.3 and $269.5 \mu \mathrm{M}$, respectively) and normal lung epithelial cells HPL1A $\left(\mathrm{IC}_{50}\right.$ values of 78.3 and $177.5 \mu \mathrm{M}$, respectively) (Table I).

cis- and trans-suffruticosol D induce apoptosis in A549 lung cancer cells. To find out whether these cytotoxic properties 
A

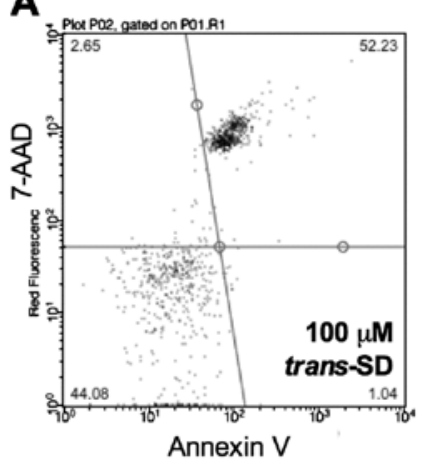

B

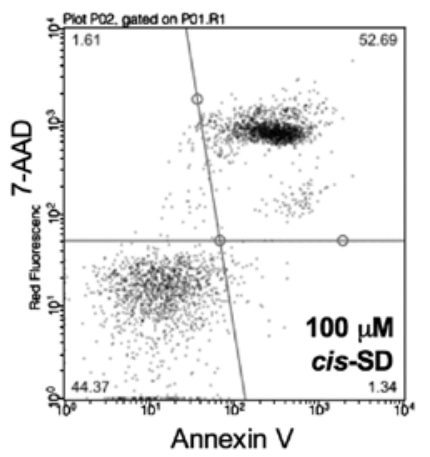

C

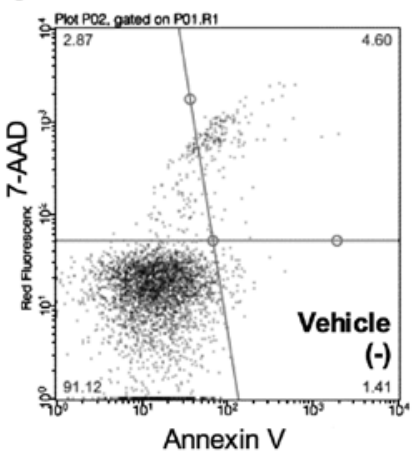

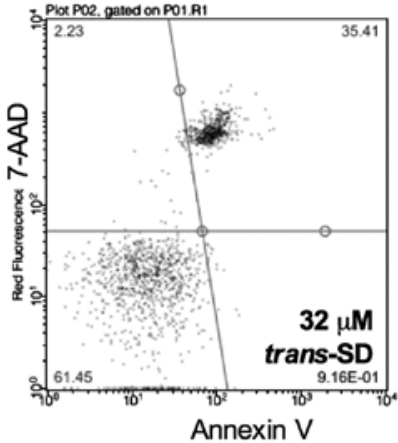
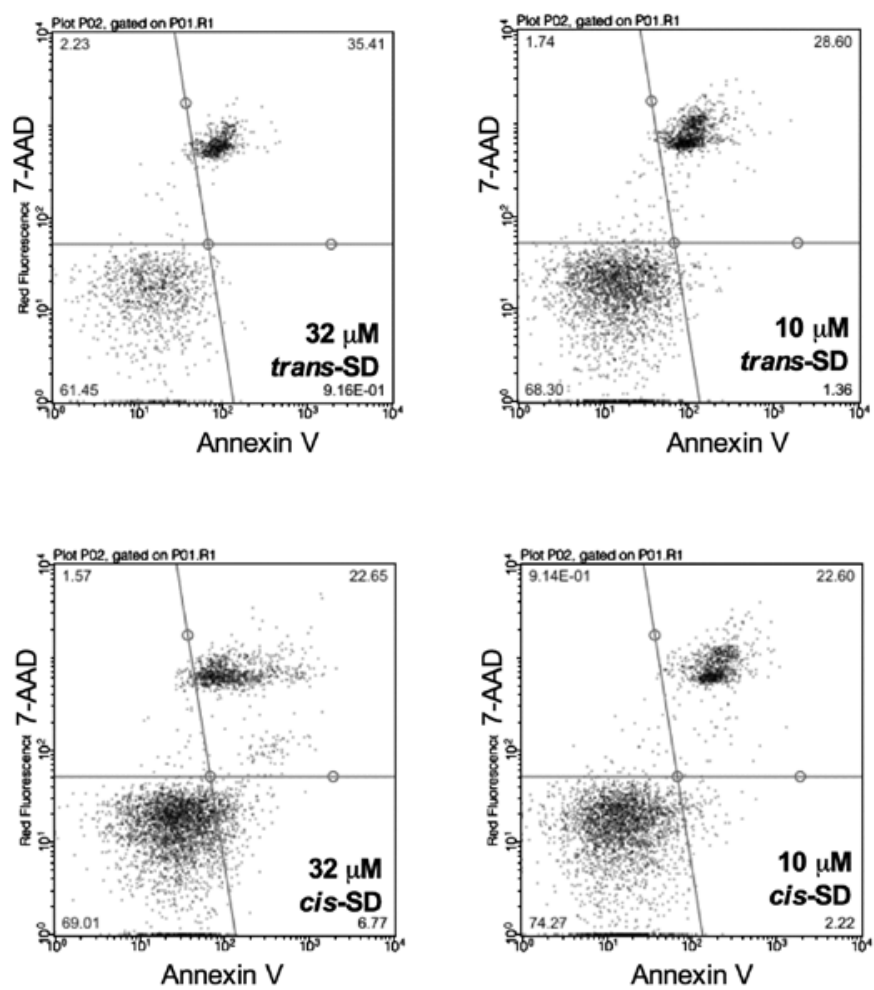

D

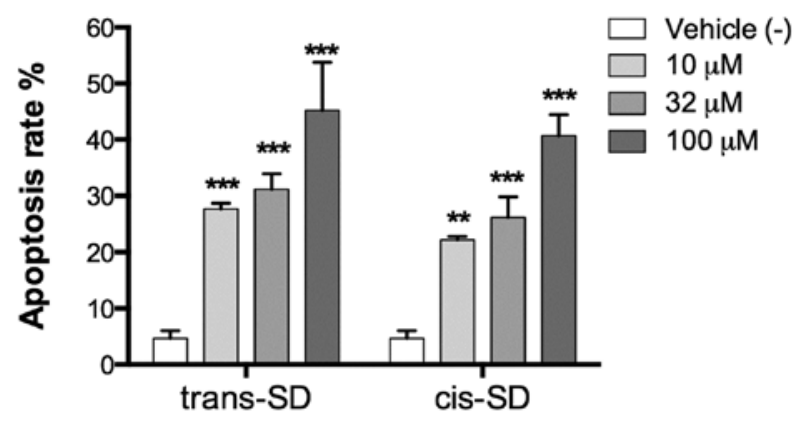

E

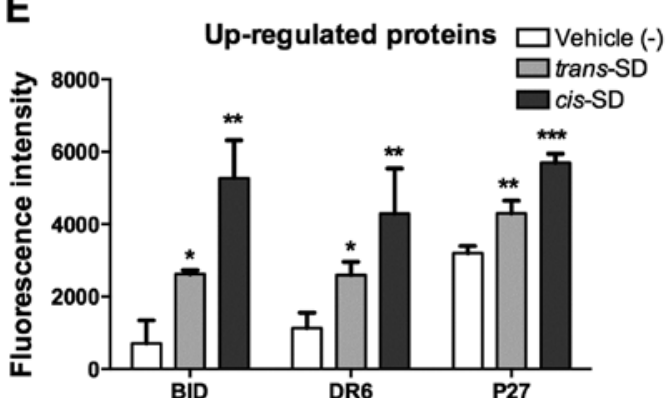

F

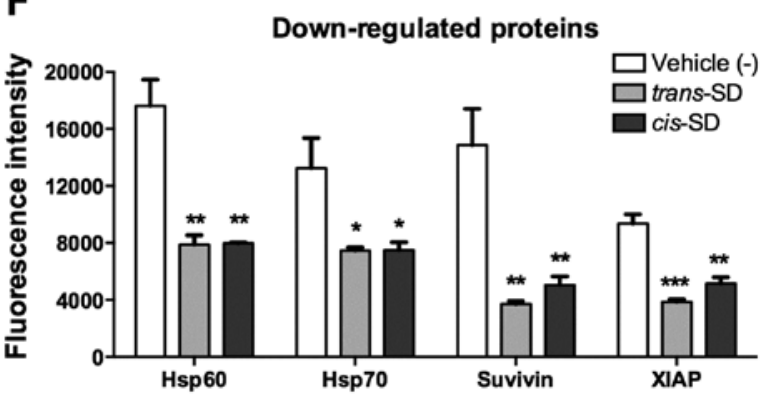

Figure 2. Induction of apoptosis by cis- and trans-suffruticosol D in A549 cells. After 24-h treatment by cis- or trans-suffruticosol D, A549 cells were stained with Annexin V/7-AAD, and the percentage of apoptotic cells was assessed by flow cytometry. Cells treated with the vehicle only served as a negative control. (A-C) Annexin V/7-AAD double staining of A549 cells treated with various concentrations of cis- or trans-suffruticosol D. (D) Percentage of apoptotic cells induced by cis- or trans-suffruticosol D. (E and F) Effect of cis- or trans-suffruticosol D on key regulatory proteins of apoptosis. The error bars indicate the standard deviation from three experiments. ${ }^{*} \mathrm{P} \leq 0.05 ;{ }^{* * *} \mathrm{P} \leq 0.01 ;{ }^{* * * *} \mathrm{P} \leq 0.001$.

were due to apoptosis, we conducted an apoptosis assay using A549 cells treated with cis- or trans-suffruticosol D. Following a 24-h treatment, both compounds showed significant apoptosis induction at a wide range of concentrations compared with the non-treated cells $\left({ }^{*} \mathrm{P}<0.05,{ }^{* *} \mathrm{P}<0.01\right.$ or $\left.{ }^{* * *} \mathrm{P}<0.001\right)$ and the apoptotic effects were concentration-dependent (Fig. 2A-D). trans-suffruticosol D induced 30.1, 39.8 and $41.9 \%$ of A549 cells into apoptosis at concentrations of 10,32 and $100 \mu \mathrm{M}$, 
A
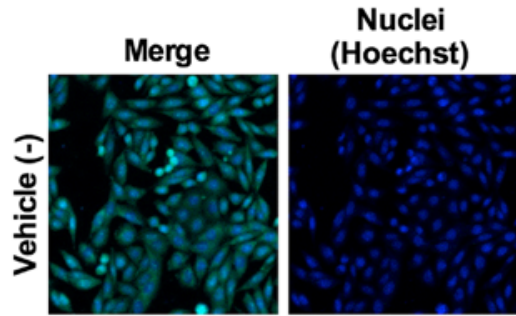

ROS
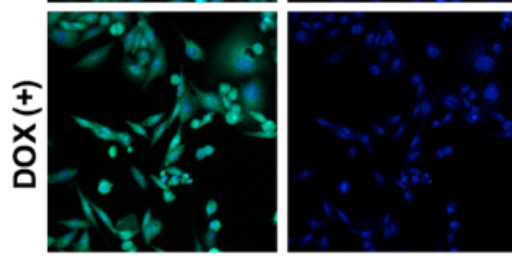

(DHE)
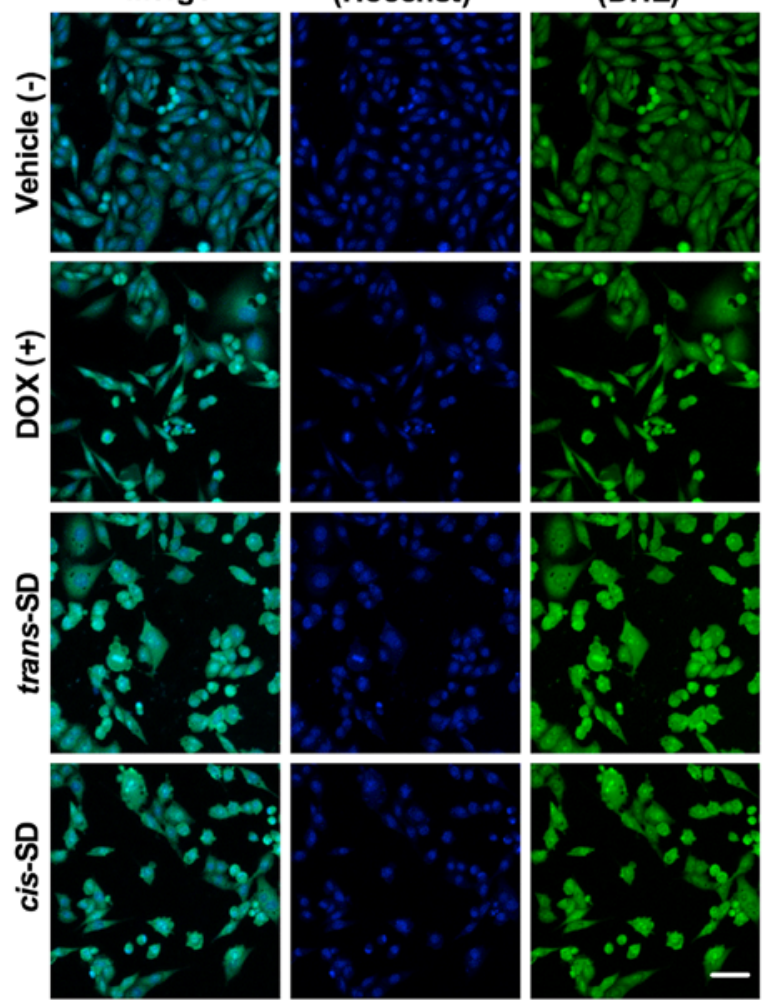

B

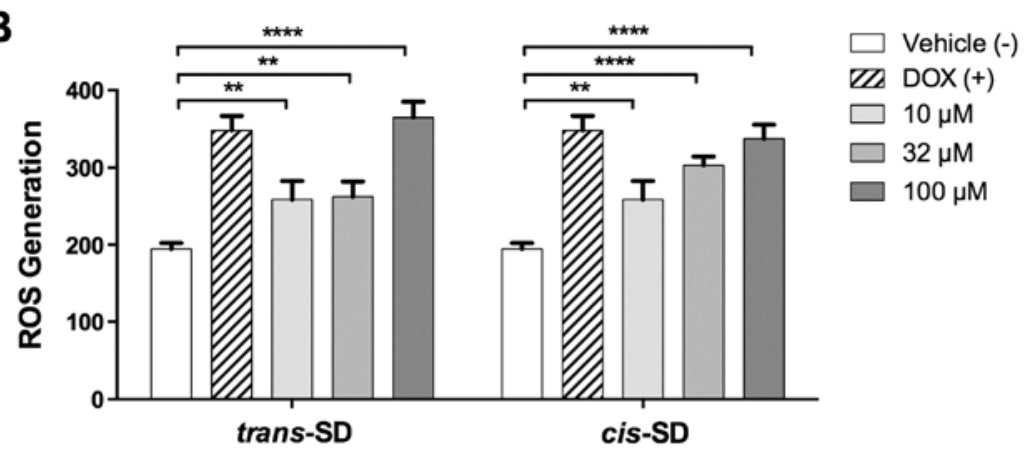

C

trans-SD

cis-SD
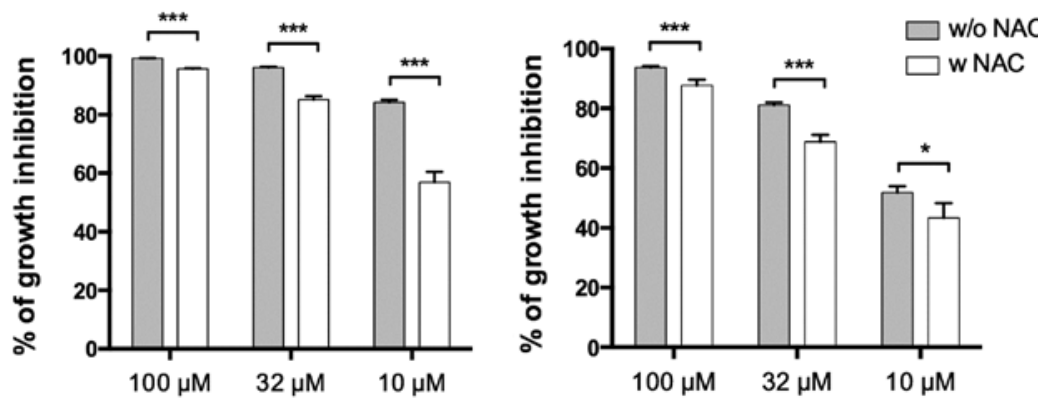

Figure 3. Induction of oxidative stress by cis- and trans-suffruticosol D in A549 cells. A549 cells were treated with various concentrations of cis- or transsuffruticosol D for $24 \mathrm{~h}$, then stained with Hoechst and DHE dye. Cells treated with doxorubicin served as a positive control, and cells treated with vehicle only served as a negative control. The ROS levels were measured by the fluorescent intensity of DHE that was converted to ethidium bromide. (A) Fluorescent cell images by the HCS reader. Scale bar, $100 \mu \mathrm{m}$. (B) ROS levels in A549 cells treated with various concentrations of cis- or trans-suffruticosol D. (C) The anti-oxidant NAC attenuated the cell death of A549 cells induced by cis- or trans-suffruticosol D. The error bars indicate the standard deviation from three experiments. ${ }^{*} \mathrm{P} \leq 0.05 ;{ }^{* *} \mathrm{P} \leq 0.01 ;{ }^{* * *} \mathrm{P} \leq 0.001$.

respectively. cis-suffruticosol D induced 22.2, 27.1 and $45.3 \%$ of A549 cells into apoptosis at concentrations of 10,32 and $100 \mu \mathrm{M}$, respectively.
Next, we performed an apoptotic protein array analysis to investigate the effect of cis- and trans-suffruticosol D on apoptotic proteins. Two proteins from the inhibitor of apoptosis 
A

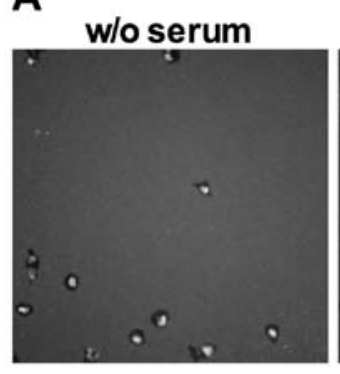

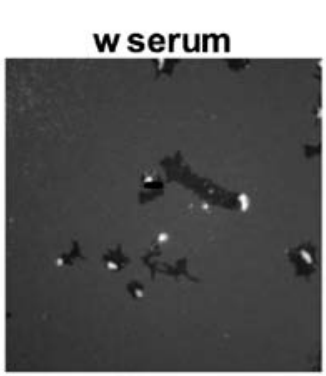

B

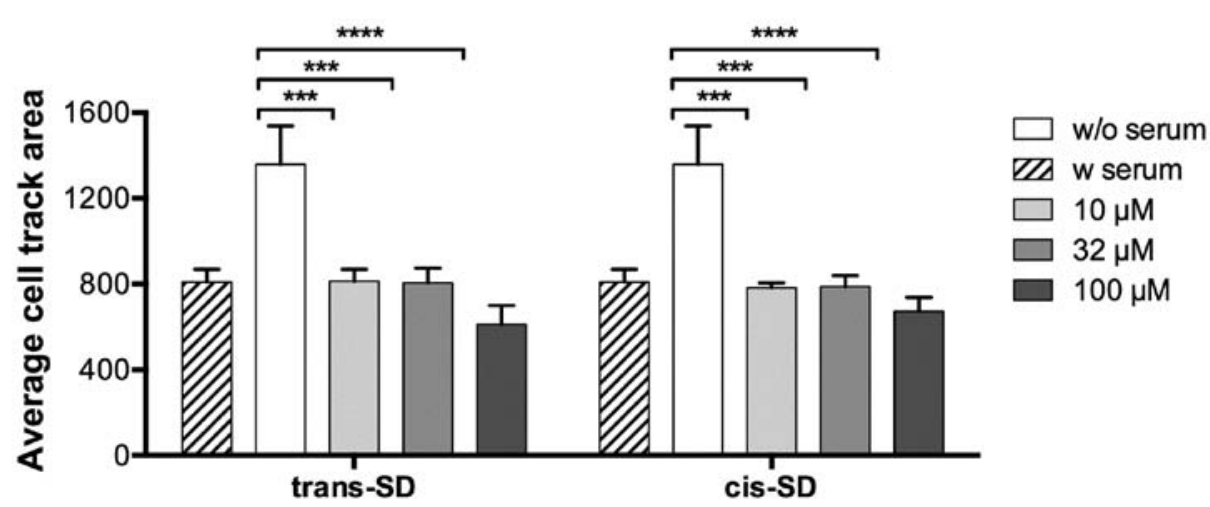

Figure 4. Cell motility changes induced by cis- and trans-suffruticosol D in A549 cells. A549-GFP cells were seeded in a 96-well plate with a monolayer of fluorescent beads. After treatment with cis- or trans-suffruticosol D for $18 \mathrm{~h}$, individual cell movement was evaluated by measuring the fluorescent track area. Cells treated with serum-free medium served as a negative control and cells treated with medium containing $10 \%$ serum served as a positive control. (A) Fluorescent track area showing the movement of the cells. Scale bar, $200 \mu \mathrm{m}$. (B) Measurement of the cell track areas of cells treated with various concentrations of cis- or trans-suffruticosol D. The error bars indicate the standard deviation from three experiments. ${ }^{*} \mathrm{P} \leq 0.05 ;{ }^{* *} \mathrm{P} \leq 0.01 ;{ }^{* * *} \mathrm{P} \leq 0.001$.

proteins family (IAPs), X-linked inhibitor of apoptosis protein (XIAP) and survivin, as well as the heat shock proteins Hsp60 and Hsp70, showed significant downregulation after treatment by cis- and trans-suffruticosol D (Fig. 2E). Whereas, death receptor 6 (DR6), also known as tumor necrosis factor receptor superfamily member 21 (TNFRSF21), the cyclin-dependent kinase inhibitor 1B (p27), and the BH3 interacting-domain death agonist (BID), were upregulated by both cis- and transsuffruticosol D (Fig. 2F).

cis- and trans-suffruticosol D induce ROS generation in A549 lung cancer cells. We examined the cellular ROS levels in A549 cells to determine whether cis- and trans-suffruticosol D induced oxidative stress. As shown in Fig. 3A, both cis- and trans-suffruticosol D converted non-fluorescent DHE to fluorescent ethidium, which binds to DNA, suggesting they induced ROS generation in A549 cells. Quantitative data showed both compounds significantly induced ROS generation in a concentration-dependent manner $\left({ }^{* *} \mathrm{P}<0.01\right.$, ${ }^{* * *} \mathrm{P}<0.001$ or $\left.{ }^{* * * *} \mathrm{P}<0.0001\right)$. After treatment for $24 \mathrm{~h}$, transsuffruticosol increased the ROS levels by $32.8,34.6$ and $87.2 \%$ at concentrations of 10,32 and $100 \mu \mathrm{M}$, respectively, while cis-suffruticosol increased the ROS levels by 32.8, 55.6 and $73.1 \%$ at concentrations of 10,32 , and $100 \mu \mathrm{M}$, respectively, in A549 cells (Fig. 3B). To further investigate whether the cytotoxicity induced by cis- and trans-suffruticosol D was associated with ROS levels, we co-treated A549 cells with the anti-oxidant N-acetyl-L-cysteine (NAC) and different concentrations of cis- or trans-suffruticosol D for $48 \mathrm{~h}$. We observed that $10 \mathrm{mM}$ NAC attenuated the cell death induced by cis- or trans-suffruticosol D in A549 cells at all of the concentrations that were tested (Fig. 3C).

cis- and trans-suffruticosol D inhibit the motility of A549 lung cancer cells. To test if cis- and trans-suffruticosol D affected cancer cell motility, we measured the size of the tracks generated by migrating cells after treatment, which is proportional to the magnitude of cell movement. As shown in Fig. 4A, A549 cells treated with cis- or trans-suffruticosol D in serum-containing medium showed less motility activity evidenced by a smaller track area per cell than the untreated cells. Both cis- and transsuffruticosol D significantly inhibited cell movement at all the concentrations that were tested in A549 cells $\left({ }^{* * *} \mathrm{P}<0.001\right.$ or ${ }^{* * * *} \mathrm{P}<0.0001$ ) (Fig. 4B). trans-suffruticosol D decreased the A549 cell motility by $40.7,40.7$ and $54.9 \%$ at concentrations of 10,32 and $100 \mu \mathrm{M}$, respectively, while cis-suffruticosol D decreased the A549 cell motility by $42.3 \%, 42.0$ and $50.4 \%$ at concentrations of 10,32 and $100 \mu \mathrm{M}$, respectively.

cis-and trans-suffruticosol D decreased mitochondrial membrane potential in A549 cells. To determine the cytotoxic effect of cis- and trans-suffruticosol D in human lung cancer cells, we measured three cell health parameters, nuclear morphology, cell membrane permeability and mitochondrial membrane potential changes, using an HCS reader. As shown in Fig. 5, in the mitochondrial potential channel, untreated A549 cells exhibited bright fluorescent intensity, indicating intact mitochondrial membranes. In comparison, in cells treated with cis- or trans-suffruticosol D the fluorescent intensity of the dye was significantly decreased at all tested 
A
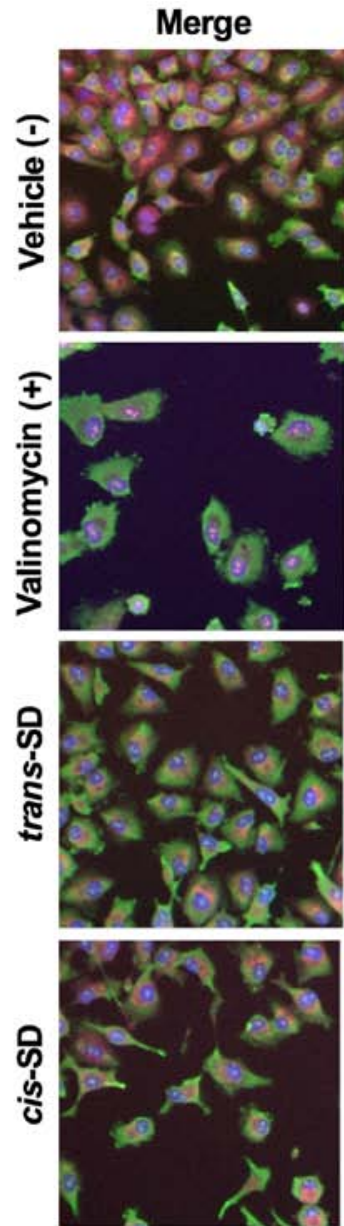

B

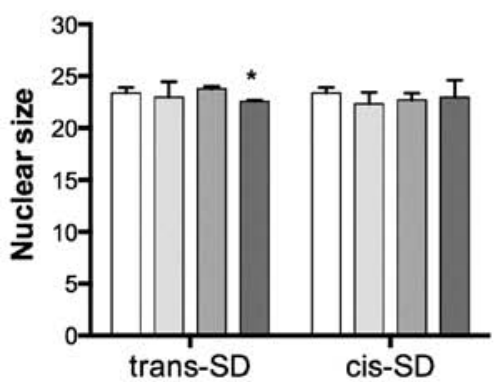

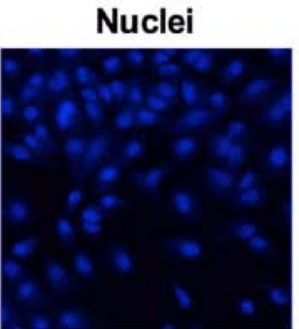

Cell permebility Membrane potential
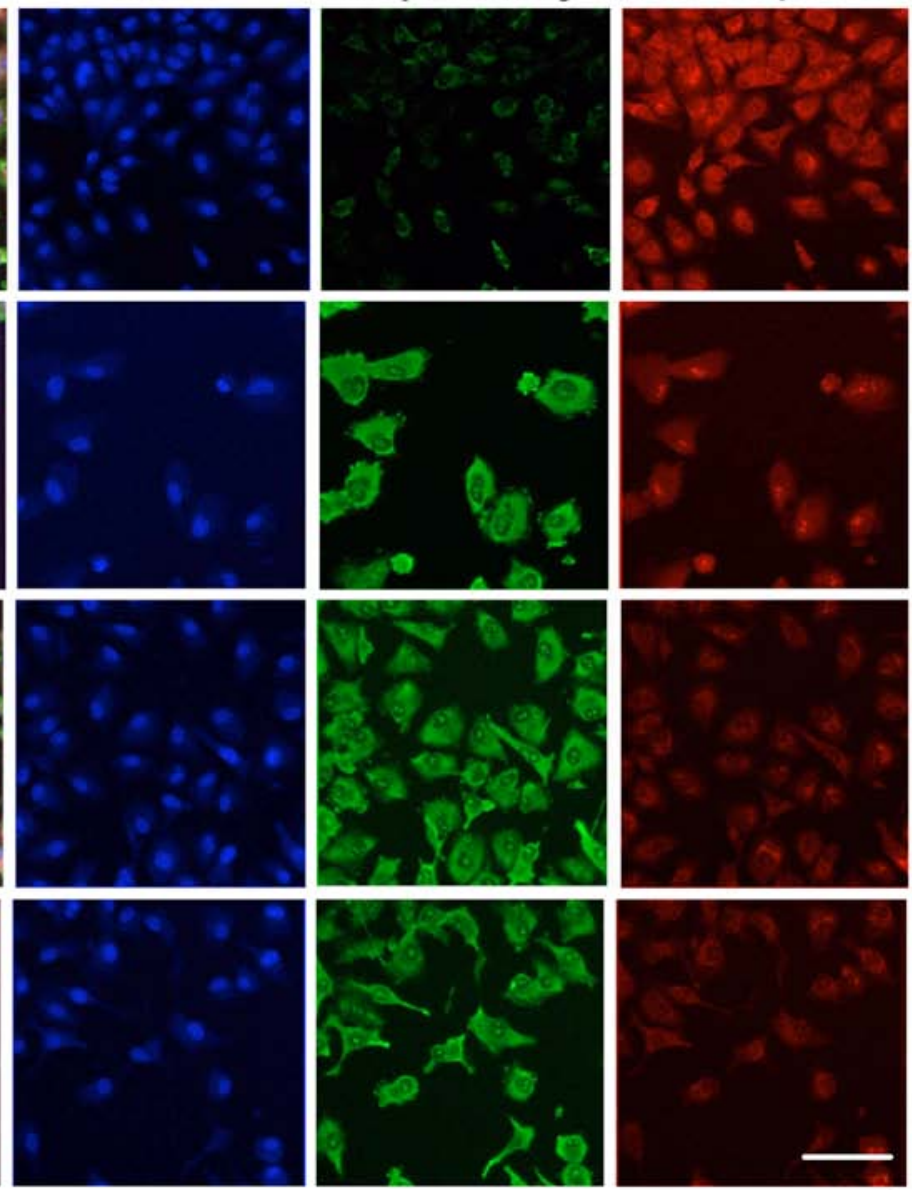

C
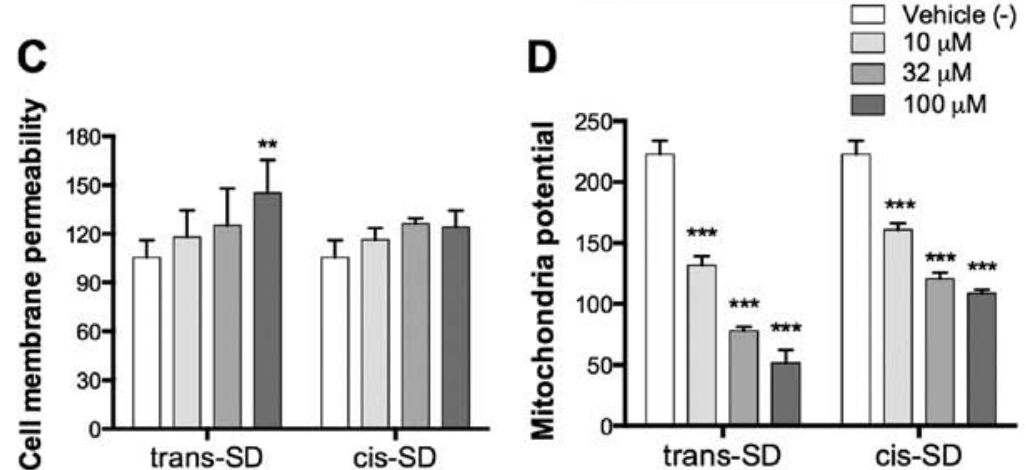

Figure 5. Multi-parameter cytotoxicity induced by cis- and trans-suffruticosol D in A549 cells. A549 cells were treated with various concentrations of cis- or trans-suffruticosol D for $24 \mathrm{~h}$, then stained with three dyes simultaneously (Hoechst, cell permeability dye and mitochondrial membrane potential dye). Cells treated with vehicle only served as a negative control and cells treated with $10 \mu \mathrm{M}$ valinomycin served as a positive control. (A) Fluorescent cell images by HCS reader. Scale bar, $100 \mu \mathrm{m}$. (B-D) Evaluation of nuclear size, cell permeability and mitochondrial membrane potential of cells treated with cis- or transsuffruticosol D. The error bars indicate the standard deviation from three experiments. ${ }^{*} \mathrm{P} \leq 0.05 ;{ }^{* *} \mathrm{P} \leq 0.01 ;{ }^{* * *} \mathrm{P} \leq 0.001$.

concentrations, indicating that cis- and trans-suffruticosol D induced a significant decrease of the mitochondrial membrane potential in A549 cells $\left({ }^{* * *} \mathrm{P}<0.001\right)$. We also observed nuclei shrinkage and increased cell membrane permeability in cells treated with a high-concentration $(100 \mu \mathrm{M})$ of trans-suffruticosol $\mathrm{D}\left({ }^{*} \mathrm{P}<0.05\right.$ or $\left.{ }^{* *} \mathrm{P}<0.01\right)$. However, no significant change was detected in nuclear size and cell membrane permeability in cells treated with $c i s$-suffruticosol D.

cis- and trans-suffruticosol D inhibit TNF- $\alpha$-induced NF- $\kappa B$ activation. We performed western blot analysis to examine the effects of cis-and trans-suffruticosol D on the expression of NF- $\kappa \mathrm{B}$ in A549 cells. As shown in Fig. 6A, upon TNF- $\alpha$ stimulation, overexpression of phosphorylated NF- $\mathrm{B}$ p65 was detected, and the overexpression was significantly inhibited by cis- and trans-suffruticosol D. In trans-suffruticosol D-treated cells, the expression of phosphorylated NF- $\kappa$ B p65 was almost completely blocked, and in cis-suffruticosol D-treated cells, the expression of phosphorylated NF- $\mathrm{B}$ p65 was blocked as effectively as the blockage caused by the Bay11-7082 inhibitor control.

Next, we used HCS analysis to test whether cis- or transsuffruticosol D could block NF- $\kappa \mathrm{B}$ nuclear translocation in A549 cells. As shown in Fig. 6B, NF- $\kappa$ B fluorescent staining 
A

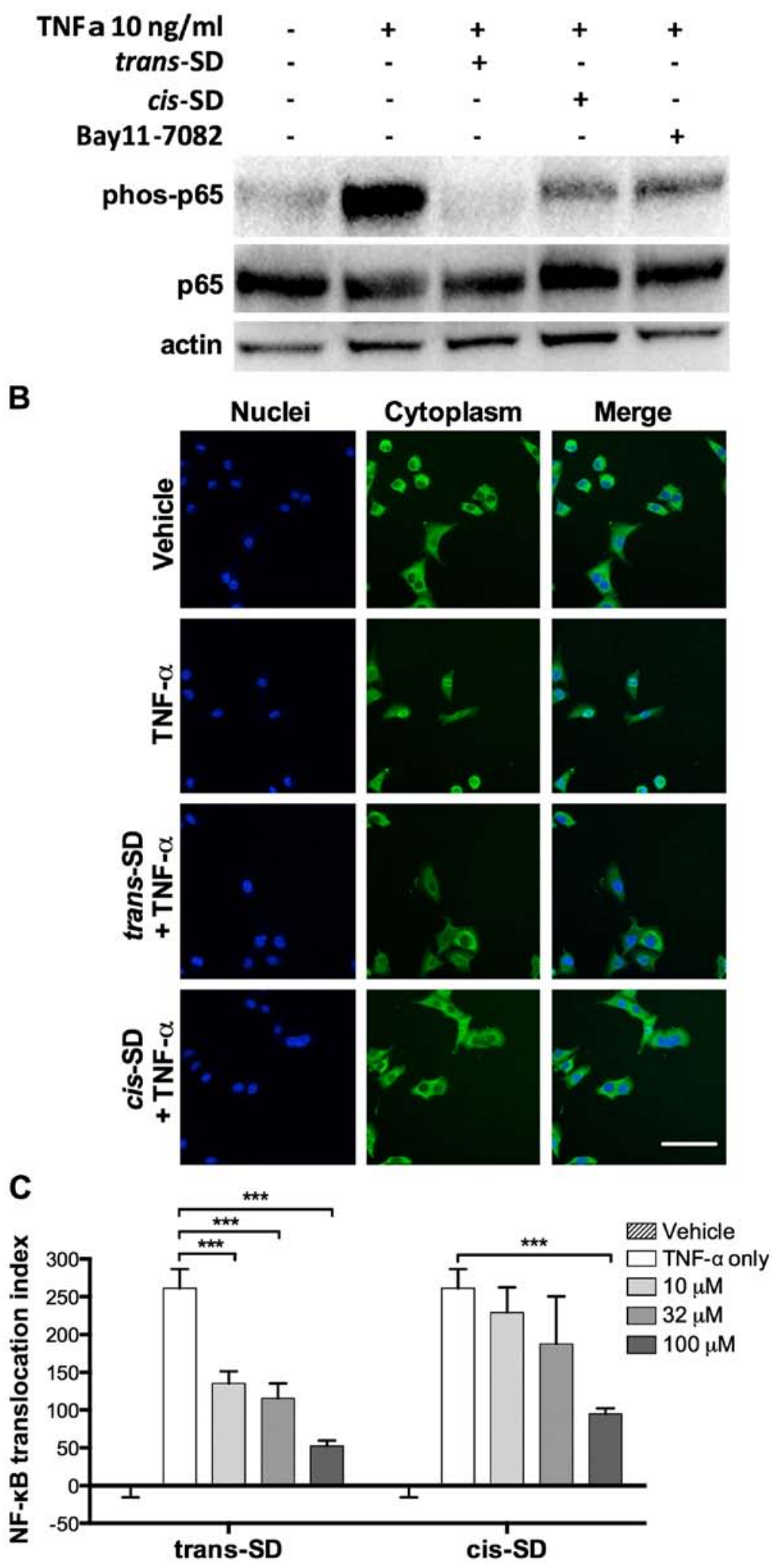

Figure 6. Inhibition of NF-kB translocation by cis- and trans-suffruticosol D in A549 cells. A549 cells were treated with various concentrations of cis- or trans-suffruticosol D for $4 \mathrm{~h}$ and then stimulated with $25 \mathrm{ng} / \mathrm{ml} \mathrm{TNF}-\alpha$ for $30 \mathrm{~min}$. Cells treated with TNF- $\alpha$ alone or the vehicle only served as controls. The $\mathrm{NF}-\mathrm{\kappa B}$ translocation index was measured by the fluorescent intensity difference between the nucleus and cytoplasm. (A) Western blot analysis of the expression

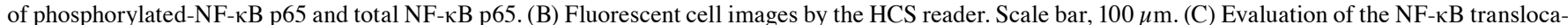
tion index in A549 cells. The error bars indicate the standard deviation from three experiments. ${ }^{*} \mathrm{P} \leq 0.05 ;{ }^{* *} \mathrm{P} \leq 0.01 ;{ }^{* * * *} \mathrm{P} \leq 0.001$.

remained in the cytoplasmic area and no fluorescence was detected in the nuclear area in non-treated cells, however, in cells treated with TNF- $\alpha$ the NF-kB fluorescent staining was detected in the nuclear area, indicating that NF- $\kappa \mathrm{B}$ was translocated from the cytoplasm to the nucleus. In A549 cells treated with cis- or trans-suffruticosol D, NF- $\kappa \mathrm{B}$ fluorescent 


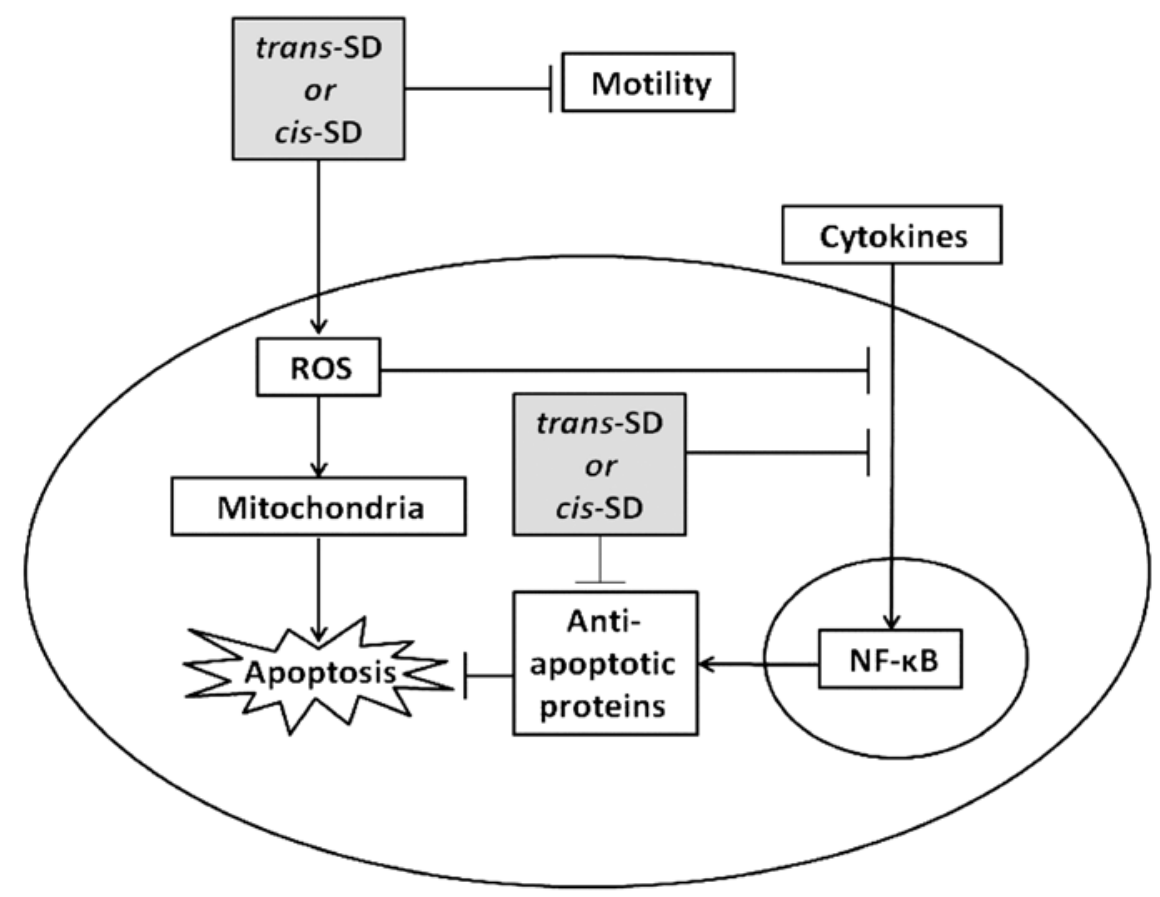

Figure 7. Proposed cytotoxicity mechanism of cis-and trans-suffruticosol D.

staining remained in the cytoplasm, suggesting that NF- $\mathrm{\kappa B}$ translocation to the nucleus was blocked. Treatment with trans-suffruticosol D at all the tested concentrations, caused a significant inhibition of NF- $\kappa \mathrm{B}$ activation $\left.{ }^{* * *} \mathrm{P}<0.001\right)$ (Fig. 6C). In contrast, treatment with cis-suffruticosol D only caused a significant inhibition of NF- $\mathrm{KB}$ at $100 \mu \mathrm{M}$ $\left({ }^{* * *} \mathrm{P}<0.001\right)$.

\section{Discussion}

Oligostilbenes have been widely considered to be valuable resources of antitumor agents. Previously, two novel oligostilbenes, cis- and trans-suffruticosol D, were extracted from the seeds of $P$. suffruticosa, but their antitumor activities were not determined. In this study, we found that both of these oligostilbenes exhibited remarkable anti-proliferation activities against several types of cancer cell lines, and their cytotoxicity effects and related mechanisms were investigated.

trans-suffruticosol D exhibited lower $\mathrm{IC}_{50}$ values (9.93-20.8 $\mu \mathrm{M})$ than cis-suffruticosol $\mathrm{D}(13.42-46.79 \mu \mathrm{M})$ in all of the cancer cell lines that were tested, indicating that trans-suffruticosol D is more cytotoxic than its cis-isomer. Consistent with this conclusion, trans-suffruticosol D had stronger effects than $c i s$-suffruticosol D on three cytotoxicity parameters, changes in nuclear size, cell membrane permeability and mitochondrial transmembrane potential. trans-suffruticosol D also showed higher inhibition activity of NF- $\kappa B$ activation than cis-suffruticosol D. These observations are consistent with a previous report, which showed that transresveratrol had stronger cytotoxicity than its $c i s$-isomer (19). In addition, both chemicals showed selective cytotoxicity against cancer cell lines versus a normal cell line.

Cancer cells usually develop the ability to escape apoptosis (programmed cell death), which is a homeostatic mechanism to maintain cell populations in the body (20). Hence, targeting apoptotic induction has become an important strategy of anticancer therapies. It is commonly known that there are two apoptotic pathways, the extrinsic, or the death receptor pathway, and the intrinsic, or the mitochondrial pathway. Previous studies have shown that mitochondria play a critical role in apoptosis, especially in the intrinsic apoptosis pathways $(21,22)$. Mitochondria are the main source of ROS inside the cell, and increases in ROS production can damage the mitochondrial membrane and subsequently lead to the release of pro-apoptotic proteins and cytochrome $c$, thus activating the apoptotic pathway (23-25). In this study, we found that cisand trans-suffruticosol D induced apoptosis in A549 lung cancer cells after 24-h treatment in a concentration-dependent manner. Both oligostilbenes significantly decreased the mitochondrial membrane potential in lung cancer cells, suggesting they might induce the mitochondrial apoptosis pathway. Since both chemicals significantly increased cellular ROS levels in lung cancer cells and their cytotoxicity was associated with ROS levels as shown by the NAC attenuation assay, it can be speculated that the excessive ROS induced by cis- and transsuffruticosol $\mathrm{D}$ act as an apoptosis mediator by damaging the mitochondrial membrane, causing the release of the mitochodria's contents, which eventually leads to apoptosis. In addition, cis- and trans-suffruticosol D affected the expression of several key regulators involved in apoptosis; XIAP, survivin, Hsp60 and Hsp70 were downregulated, while BID, DR6 and p27 were upregulated.

XIAP and survivin are known apoptosis inhibitors that prevent apoptosis by inhibiting caspase-3, -7, and -9 (26-28). Downregulation of XIAP or survivin has been demonstrated to inhibit the progression of cancer and increase the sensitivity of cancer cells to chemo-reagents (29-32). Heat shock proteins Hsp60 and Hsp70 are chaperones that play essential roles 
in tumor cell survival and proliferation due to their ability to block both the intrinsic and extrinsic apoptosis pathways $(33,34)$. BID is a pro-apoptotic member of the $\mathrm{Bcl}-2$ protein family, and is a mediator of mitochondrial damage induced by caspase- 8 (35). p27, the cyclin-dependent kinase inhibitor, controls the cell cycle progression at G1 by preventing the activation of cyclin E-Cdk2 or cyclin D1-Cdk4 complexes (36,37). DR6, also known as TNFRSF21, is a member of the death receptor family, which induces apoptosis in mammalian cells and its apoptotic function is inhibited by survivin (38). Downregulation of XIAP, survivin, Hsp60 and Hsp70, as well as upregulation of BID, DR6 and p27 by cis- and transsuffruticosol D at least partially contribute to the apoptotic effect of cis- and trans-suffruticosol D.

Tumor cells have the ability to migrate to surrounding tissues and organs through reorganization of the actin cytoskeleton $(39,40)$. Most of the fatality from tumors occurs when cells move from the initial organs where they originated (41). Therefore, control of cancer cell motility and migration is an essential issue in cancer treatment and represents a new opportunity for a potential tumor therapy (42). cis- and transsuffruticosol D significantly inhibited the mobility of lung cancer cells after treatment for $18 \mathrm{~h}$ at all the concentrations that were tested. Therefore, both chemicals exhibit therapeutic potential as an inhibitor of cancer cell mobility.

The NF- $\kappa \mathrm{B}$ pathway is known to control cell growth and survival, and the transcription factor $\mathrm{NF}-\kappa \mathrm{B}$ has been found to be permanently activated in various tumors (21). Activation of NF- $\kappa \mathrm{B}$ in cancer cells is often associated with drug resistance as both radio- and chemo-therapies induce constitutive activation of the $\mathrm{NF}-\kappa \mathrm{B}$ pathway (43). Therefore, a compound's ability to block the NF- $\kappa \mathrm{B}$ pathway is important for the efficacy of cancer therapy (44). In this study, we evaluated cis- and trans-suffruticosol D for their abilities to inhibit TNF- $\alpha$ induced NF- $\kappa$ B activation in lung cancer cells. After a 4-h treatment both chemicals significantly blocked NF- $\mathrm{BB}$ p65 phosphorylation as well as NF- $\mathrm{NB}$ p65 translocation from the nucleus to the cytoplasm, suggesting they might act as

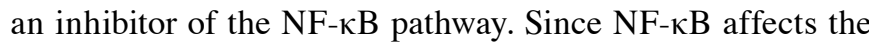
transcription of a number of anti-apoptotic proteins, including cellular inhibitor of apoptosis proteins (cIAPs), XIAP, bcl-2, bcl-XL, and FADD-like IL-1 $\beta$-converting enzyme-inhibitory protein (c-FLIP), blocking $\mathrm{NF}-\kappa \mathrm{B}$ nuclear translocation decreases the expression of anti-apoptotic proteins and subsequently promotes apoptosis. In addition, several studies have shown that an increase of ROS can block the NF- $\kappa \mathrm{B}$ pathway by the inhibition of cytokines, such as TNF and IL-1 (45). Because cis- and trans-suffruticosol D increased ROS generation in lung cancer cells, the block in the NF- $\mathrm{B}$ pathway may be associated with the inhibition of the inducer cytokines by excessive ROS.

In conclusion, this study provides evidence that $\mathrm{cis}$ - and trans-suffruticosol D have promising antitumor activities. Both compounds selectively inhibited the growth of various cancer cells, induced apoptosis in A549 lung cancer cells, as well as inhibited A549 cell movement. The induction of apoptosis may be associated with ROS generation and inhibi-

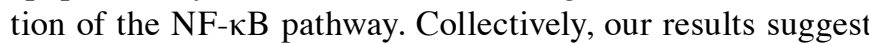
a potential mechanism for the cytotoxicity of cis- and transsuffruticosol D. As shown in Fig. 7, in A549 lung cancer cells, cis- and trans-suffruticosol D trigger oxidative stress, which in turn leads to mitochondrial damage, blocks NF- $\kappa$ B activation and ultimately triggers apoptosis. Our findings suggest that both cis- and trans-suffruticosol D have promising chemotherapeutic potential for treating cancer.

\section{Acknowledgements}

We thank the Tennessee Center of Botanical Medicine Research (TCBMR) for providing the funding for this study. We also thank Dr Takashi Takahashi at Nagoya University for the HPL1A cell line.

\section{References}

1. Cai Y, Luo Q, Sun M and Corke H: Antioxidant activity and phenolic compounds of 112 traditional Chinese medicinal plants associated with anticancer. Life Sci 74: 2157-2184, 2004.

2. Zhang Q and Gong H: Clinical Practice of Anticancer Traditional Chinese Medicines. People's Health Publishing House, Beijing, 1998.

3. Bo QM, Wu ZY, Shun QS, Bao XS, Mao ZS, Ha SQ, Lu SY and Huang JM: A Selection of the Illustrated Chinese Anti-Cancer Herbal Medicines. Shanghai Science and Technology Literature Press, Shanghai, 2002.

4. Parekh HS, Liu G and Wei MQ: A new dawn for the use of traditional Chinese medicine in cancer therapy. Mol Cancer 8: 21, 2009.

5. He CN, Peng Y, Xu LJ, Liu ZA, Gu J, Zhong AG and Xiao PG: Three new oligostilbenes from the seeds of Paeonia suffruticosa. Chem Pharm Bull (Tokyo) 58: 843-847, 2010.

6. Chinese Pharmacopoeia Commission: In: Chinese Pharmacopoeia China Medical Scientific and Technological Press, Beijing, pp160-161, 2010.

7. He CN, Peng Y, Wu QL, Xiao W, Peng B, Wang Z and Xiao PG: Simultaneous determination of ten stilbenes in the seeds of Paeonia species using HPLC-DAD. J Liquid Chromatogr Relat Technol 36: 1708-1724, 2013.

8. He CN, Peng Y, Zhang YC, Xu LJ, Gu J and Xiao PG: Phytochemical and biological studies of Paeoniaceae. Chem Biodivers 7: 805-838, 2010.

9. Shen T, Xie CF, Wang XN and Lou HX: Stilbenoids. In: Natural Products. Springer, pp1901-1949, 2013.

10. Cai $\mathrm{T}$ and Cai Y: cis-Ampelopsin $\mathrm{E}$, a stilbene isolated from the seeds of Paeonia suffruticosa, inhibits lipopolysaccharidestimulated nitric oxide production in RAW 264.7 macrophages via blockade of nuclear factor-kappa B signaling pathway. Biol Pharm Bull 34: 1501-1507, 2011.

11. Yuk HJ, Ryu HW, Jeong SH, Curtis-Long MJ, Kim HJ, Wang Y, Song YH and Park KH: Profiling of neuraminidase inhibitory polyphenols from the seeds of Paeonia lactiflora. Food Chem Toxicol 55: 144-149, 2013.

12. Hussain S, Slevin M, Ahmed N, West D, Choudhary MI, Naz H and Gaffney J: Stilbene glycosides are natural product inhibitors of FGF-2-induced angiogenesis. BMC Cell Biol 10: 30, 2009.

13. Simoni D, Invidiata FP, Eleopra M, Marchetti P, Rondanin R, Baruchello R, Grisolia G, Tripathi A, Kellogg GE, Durrant D, et al: Design, synthesis and biological evaluation of novel stilbene-based antitumor agents. Bioorg Med Chem 17: 512-522, 2009.

14. He S, Lu Y, Jiang L, Wu B, Zhang F and Pan Y: Preparative isolation and purification of antioxidative stilbene oligomers from Vitis chunganeniss using high-speed counter-current chromatography in stepwise elution mode. J Sep Sci 32: 2339-2345, 2009.

15. Jung M, Park WH, Jung JC, Lim E, Lee Y, Oh S and Moon HI: Synthesis, structural characterization and biological evaluation of novel stilbene derivatives as potential antimalarial agents. Chem Biol Drug Des 73: 346-354, 2009.

16. Lee K, Lee JH, Ryu SY, Cho MH and Lee J: Stilbenes reduce Staphylococcus aureus hemolysis, biofilm formation, and virulence. Foodborne Pathog Dis 11: 710-717, 2014.

17. Shukla Y and Singh R: Resveratrol and cellular mechanisms of cancer prevention. Ann NY Acad Sci 1215: 1-8, 2011. 
18. Whitlock NC and Baek SJ: The anticancer effects of resveratrol: Modulation of transcription factors. Nutr Cancer 64: 493-502, 2012.

19. Pettit GR, Grealish MP, Jung MK, HamelE, Pettit RK, Chapuis JC and Schmidt JM: Antineoplastic agents. 465. Structural modification of resveratrol: Sodium resverastatin phosphate. J Med Chem 45: 2534-2542, 2002.

20. Kasibhatla S and Tseng B: Why target apoptosis in cancer treatment? Mol Cancer Ther 2: 573-580, 2003.

21. Cheah SC, Appleton DR, Lee ST, Lam ML, Hadi AHA and Mustafa MR: Panduratin A inhibits the growth of A549 cells through induction of apoptosis and inhibition of NF-kappaB translocation. Molecules 16: 2583-2598, 2011.

22. Ly JD, Grubb DR and Lawen A: The mitochondrial membrane potential $(\Delta \psi \mathrm{m})$ in apoptosis; an update. Apoptosis 8: 115-128, 2003.

23. Kannan $\mathrm{K}$ and Jain SK: Oxidative stress and apoptosis. Pathophysiology 7: 153-163, 2000.

24. Ozben T: Oxidative stress and apoptosis: Impact on cancer therapy. J Pharm Sci 96: 2181-2196, 2007.

25. Sosa V, Moliné T, Somoza R, Paciucci R, Kondoh $\mathrm{H}$ and LLeonart ME: Oxidative stress and cancer: An overview. Ageing Res Rev 12: 376-390, 2013

26. Suzuki Y, Nakabayashi Y, Nakata K, Reed JC and Takahashi R: $\mathrm{X}$-linked inhibitor of apoptosis protein (XIAP) inhibits caspase-3 and -7 in distinct modes. J Biol Chem 276: 2705827063, 2001

27. Schimmer AD, Dalili S, Batey RA and Riedl SJ: Targeting XIAP for the treatment of malignancy. Cell Death Differ 13: 179-188, 2006.

28. Ryan BM, O'Donovan N and Duffy MJ: Survivin: A new target for anti-cancer therapy. Cancer Treat Rev 35: 553-562, 2009.

29. Hu Y, Cherton-Horvat G, Dragowska V, Baird S, Korneluk RG, Durkin JP, Mayer LD and LaCasse EC: Antisense oligonucleotides targeting XIAP induce apoptosis and enhance chemotherapeutic activity against human lung cancer cells in vitro and in vivo. Clin Cancer Res 9: 2826-2836, 2003.

30. He X, Khurana A, Maguire JL, Chien J and Shridhar V: HtrA1 sensitizes ovarian cancer cells to cisplatin-induced cytotoxicity by targeting XIAP for degradation. Int J Cancer 130: 1029-1035, 2012.

31. Oost TK, Sun C, Armstrong RC, Al-Assaad AS, Betz SF, Deckwerth TL, Ding H, Elmore SW, Meadows RP, Olejniczak ET, et al: Discovery of potent antagonists of the antiapoptotic protein XIAP for the treatment of cancer. J Med Chem 47: 4417-4426, 2004.
32. Mita AC, Mita MM, Nawrocki ST and Giles FJ: Survivin: Key regulator of mitosis and apoptosis and novel target for cancer therapeutics. Clin Cancer Res 14: 5000-5005, 2008.

33. Cappello F, Conway de Macario E, Marasà L, Zummo G and Macario AJ: Hsp60 expression, new locations, functions and perspectives for cancer diagnosis and therapy. Cancer Biol Ther 7: 801-809, 2008.

34. Murphy ME: The HSP70 family and cancer. Carcinogenesis 34: 1181-1188, 2013.

35. Luo X, Budihardjo I, Zou H, Slaughter C and Wang X: Bid, a $\mathrm{Bcl} 2$ interacting protein, mediates cytochrome $\mathrm{c}$ release from mitochondria in response to activation of cell surface death receptors. Cell 94: 481-490, 1998.

36. Yamamoto H, Soh JW, Shirin H, Xing WQ, Lim JT, Yao Y, Slosberg E, Tomita N, Schieren I and Weinstein IB: Comparative effects of overexpression of p27Kip1 and p21Cip1/Waf1 on growth and differentiation in human colon carcinoma cells. Oncogene 18: 103-115, 1999.

37. Nickeleit I, Zender S, Kossatz U and Malek NP: p27kip1: A target for tumor therapies? Cell Div 2: 13, 2007.

38. Kasof GM, Lu JJ, Liu D, Speer B, Mongan KN, Gomes BC and Lorenzi MV: Tumor necrosis factor-alpha induces the expression of DR6, a member of the TNF receptor family, through activation of NF-kappaB. Oncogene 20: 7965-7975, 2001.

39. Yamazaki D, Kurisu S and Takenawa T: Regulation of cancer cell motility through actin reorganization. Cancer Sci 96: 379-386, 2005.

40. Olson MF and Sahai E: The actin cytoskeleton in cancer cell motility. Clin Exp Metastasis 26: 273-287, 2009.

41. Wells A, Grahovac J, Wheeler S, Ma B and Lauffenburger D: Targeting tumor cell motility as a strategy against invasion and metastasis. Trends Pharmacol Sci 34: 283-289, 2013.

42. Levin EG: Cancer therapy through control of cell migration. Curr Cancer Drug Targets 5: 505-518, 2005.

43. Monika SA, Sharma A, Suthar SK, Aggarwal V, Lee HB and Sharma M: Synthesis of lantadene analogs with marked in vitro inhibition of lung adenocarcinoma and TNF- $\alpha$ induced nuclear factor-kappa B (NF-кB) activation. Bioorg Med Chem Lett 24: 3814-3818, 2014

44. Nakanishi $\mathrm{C}$ and Toi M: Nuclear factor-kappaB inhibitors as sensitizers to anticancer drugs. Nat Rev Cancer 5: 297-309, 2005.

45. Reuter S, Gupta SC, Chaturvedi MM and Aggarwal BB: Oxidative stress, inflammation, and cancer: How are they linked? Free Radic Biol Med 49: 1603-1616, 2010. 